\title{
SEMELHANÇAS ENTRE A FICÇÃO JURÍDICA E A FICÇÃo LITERÁRIA: OS PROCESSOS JUDICIAIS ENQUANTO NARRATIVAS ANCORADAS NA REALIDADE
}

\author{
EdNALdo Silva FERREIRA JÚNIOR ${ }^{1}$
}

\begin{abstract}
RESUMO: O objetivo do presente trabalho é analisar o quanto as narrativas processuais se assemelham às narrativas literárias. Isso porque, se o objeto de estudo da Teoria do Direito for semelhante ao objeto da Teoria Literária, a princípio, seria possível o uso de conceitos típicos desta por aquela, em uma troca de "lentes conceituais" que permitiria novas observações. Nesse sentido, este escrito utiliza-se do conceito de ficção formulado pelos literatos com o fim de demonstrar o quanto um romance, objeto de estudo da teoria literária, é assemelhado a um processo judicial, um dos objetos de estudo da teoria do direito. Por fim, conclui-se que os processos judiciais constituem verdadeiras ficções ancoradas na realidade.
\end{abstract}

PALAVRAS-CHAVE: narrativas processuais; narrativas literárias; verossimilhança; ficções ancoradas na realidade.

\section{INTRODUÇÃO}

Antes de expor o problema sobre o qual se debruça este trabalho, é preciso compreender a que tipo de relação entre Direito e Literatura ele se refere. Isso porque esse é um campo de estudo já um tanto antigo e extremamente frutífero, o qual deu - e permanece dando - origem a enfoques diferentes, cada qual com suas peculiaridades, de maneira que analisar o presente trabalho a partir de outras lentes, ainda que referentes à intersecção entre os conhecimentos jurídicos e literários, pode induzir a erros e decepções.

1 Advogado. Bacharel em Direito pela Universidade Federal de Pernambuco (UFPE), Recife, PE, Brasil. CV Lattes: http://lattes.cnpq.br/0285349792930508. E-mail: ednaldosfjunior@gmail.com. 
Por isso, é preciso, de início, esclarecer que este trabalho não utilizará um texto literário para ilustrar um problema eminentemente jurídico. E é preciso começar por essa observação porque estudar o Direito na Literatura é a forma mais comumente empregada pelos juristas para relacionar essas duas áreas do conhecimento, ao menos no Brasil ${ }^{2}$. Com ilustrar refiro-me a usar algum livro, ou o simples trecho de uma obra, para descrever questões relacionadas com a aplicação do Direito. Por exemplo, um trabalho que utilizasse Édipo rei (Sófocles, 2016), mais precisamente o personagem Édipo, para problematizar se a circunstância agravante prescrita pelo art. 61, II, e, do Código Penal Brasileiro3 ${ }^{3}$ deveria incidir sobre o assassinato de Laio, mesmo o protagonista não sabendo, à época do delito, que matava seu pai. Em tal caso, estariam sendo estudadas questões eminentemente jurídicas, tal qual a agravante penal como uma demonstração de maior reprovação social diante da conduta, assim como a teleologia do dispositivo legal citado, em um contexto fático revelado por uma obra literária.

E, quando digo que essa é a forma mais comum entre os juristas brasileiros de relacionar o direito e a literatura, não é minha intenção menosprezá-la. Tal tipo de estudo possui grande importância e deveria ser utilizado com mais frequência na academia brasileira, inclusive, como método de ensino. Como explica a teoria literária, o personagem, em toda obra, é aquele que corporifica valores, tornando-os mais evidentes ao leitor (Candido et al., 2009), de tal sorte que ilustrar a aplicação de conceitos jurídicos através de obras literárias e os dramas vividos pelos seus personagens permite ao futuro bacharel conhecer as questões valorativas envolvidas na incidência do direito sobre a vida das pessoas, em um exercício de alteridade essencial para toda atividade jurisdicional. Porém, estudar o Direito na Literatura não é o objetivo deste trabalho.

2 Embora no Brasil o interesse pelas relações entre Direito e Literatura tenha se tornado minimamente expressivo há poucos anos, na Europa e, principalmente, nos Estados Unidos, esse tema já é estudado há algumas décadas. Em virtude disto, há nesses locais uma variedade de enfoques cuja amplidão ainda inexiste na academia brasileira. Contudo, devido às limitações naturais a este tipo de trabalho, preferi reduzir minha observação ao que é produzido sobre Direito e Literatura especificamente no Brasil, espaço onde este trabalho efetivamente se insere. De toda forma, por produzir um bom panorama geral sobre o estudo das intersecções entre o Direito e a Literatura nos Estados Unidos e na Europa, com enfoque na Itália, merece destaque o estudo de M. Paola Mittica (2016).

3 “Art. 61. São circunstâncias que sempre agravam a pena, quando não constituem ou qualificam o crime: [...] II - ter o agente cometido o crime: [...] e) contra ascendente, descendente, irmão ou cônjuge”. 
Tampouco é o objetivo deste trabalho utilizar a literatura para refletir sobre os valores morais e/ou ideológicos presentes em determinada sociedade, os quais, por sua vez, compõem o ordenamento jurídico, em dados contextos históricos. Se a forma anterior é a mais comum na academia jurídica brasileira, essa é, talvez, a mais incomum. Entre os poucos trabalhos com tal enfoque, é possível destacar $A$ ciência jurídica $e$ seus dois maridos, de Luis Alberto de Warat (2000), que, através de Cortazar e Jorge Amado, procura analisar a epistemologia do direito contemporâneo contrapondo-a a uma possível "epistemologia dos desejos", encontrada, segundo o jurista argentino, na literatura.

E tal maneira de estudar as relações entre o direito e a literatura também é bastante benéfica para a educação jurídica. A literatura de um povo é um instrumento extremamente útil para perceber mais facilmente os valores que compõem aquela sociedade e, consequentemente, o seu ordenamento jurídico. Assim, na medida em que facilita a compreensão dos valores de determinada sociedade e de seu ordenamento jurídico, a literatura é fundamental para a análise de tais valores com o fim de formar um jurista democrático (Ghirardi, 2016). Ressalte-se a diferença quanto ao estudo do direito na literatura, pois aqui não se está a observar os valores envolvidos na incidência de determinada norma jurídica, as consequências relativas a pessoas específicas, mas os valores presentes na base do ordenamento jurídico enquanto um conjunto, os valores envolvidos na regulação da vida de todos. Porém, esse também não é o objetivo do presente trabalho.

O que se pretende aqui é buscar, na teoria literária, contribuições para a teoria geral e filosofia do direito. O objetivo deste trabalho é demonstrar o quanto conceitos típicos da teoria literária podem ser utilizados no estudo do direito, permitindo a este contemplar novas questões, tornadas visíveis devido ao uso das lentes conceituais provenientes daquela teoria. Por exemplo, alguns teóricos literários, como James Wood (2012), afirmam que, por vezes, na literatura, as metáforas deixam de ser percebidas como tal em razão do seu uso reiterado, o que tornaria necessária a produção de novas metáforas; nesse sentido, seria possível argumentar o mesmo que o teórico afirma sobre as metáforas literárias, mas em relação às metáforas jurídicas - como a metáfora da clareza da lei (Castro Jr., 2009)? 
Desta feita, com este propósito de estudar direito e literatura enquanto teoria literária e teoria do direito, o presente trabalho busca analisar se o conceito literário de ficção pode ser aplicado no estudo do direito, com o fim de compreender o quanto a atividade desenvolvida pelo operador do direito 4 é um tanto semelhante àquela realizada pelos autores de obras literárias.

Por vezes, ambos os ofícios são tratados como completamente diferentes e inconfundíveis. O seguinte trecho, escrito por Kafka - que, além de escritor, era bacharel em direito -, é um bom exemplo de tal reiterada oposição:

Não chama a sua atenção o fato de que falo quase como um jurista? É o convívio ininterrupto com os senhores do tribunal que me influencia tanto. Naturalmente ganho muito com isso, mas o impulso artístico em parte se perde (2013, p. 225).

$\mathrm{O}$ trecho, que pertence à obra $O$ processo, compõe o momento do romance em que Joseph K., réu de um processo judicial que não conhece, resolve procurar o pintor responsável por fazer os retratos dos juízes da localidade - o encontro gira em torno da ideia de que, devido à proximidade que mantém com os julgadores, Titorelli poderia influenciálos em favor e K.. E, no fragmento citado, Kafka de logo opõe o jurista ao artista, visto que, não à toa, o impulso artístico se perde ao conviver com os bacharelados em direito.

Porém, se olharmos de um outro ângulo - um pouco mais generoso -, os juristas não são assim tão diferentes dos artistas, ao menos dos escritores. Em seu íntimo, os juristas se relacionam com a realidade da mesma maneira que os escritores: criam um mundo inteiramente novo, sujeito às suas próprias regras, o qual, na tentativa de explicar o que entendemos por "realidade", refere-se a ela, mas sem nela se reduzir.

\footnotetext{
Esse, certamente, não é o termo mais preciso. Mas, ao menos, é mais apropriado do que jurista. Isso porque, com o uso do termo "operadores do direito", pretendo excluir da minha observação os teóricos, ou, se preferirem, os "acadêmicos", assim como os bacharéis que trabalham desempenhando funções menos convencionais, como os gestores públicos e legisladores. Quero referir-me àqueles profissionais mais próximos da solução de litígios, como os juízes, promotores, procuradores e os chamados "advogados de contencioso".
} 


\section{A FICÇÃO PARA A TEORIA LITERÁRIA: UM MUNDO NOVO SUJEITO ÀS SUAS PRÓPRIAS REGRAS}

\section{Todorov e a importância da verossimilhança na elaboração do texto literário}

Embora admita que já li poetas melhores, Vinicius de Moraes ainda é o meu preferido. E, entre os seus poemas, Balada do Mangue 5 é aquele do qual mais gosto. Nele, com o fim de retratar as péssimas condições de vida das prostitutas cariocas, que Vinicius conheceu cedo, ainda quando carregava consigo a culpa religiosa que dava origem a poemas de cunho existencial, o poetinha, ao invés de acusar tais mulheres, compara-as com frágeis e desmilinguidas dálias.

Porém, para além da beleza do poema, é interessante observar a maneira como tal obra literária interage com a realidade. Influenciado por um dado do "mundo real" (a marginalização sofrida pelas prostitutas que conhecia), Vinicius, através de um poema, concebeu um cenário onde prostitutas são flores gonocócicas, e, embora o cenário que criou não possua correspondência exata com a realidade, visto que prostitutas são mulheres, e não flores, o seu relato é aceito e elogiado pelo leitor. Isso revela um traço característico da ficção literária: embora se volte para a realidade, buscando interpretá-la, a literatura não está restrita ao "mundo real”; na verdade, a obra literária é completamente autônoma em relação à realidade.

\footnotetext{
5 "Pobres flores gonocócicas/ Que à noite despetalais/ As vossas pétalas tóxicas!/ Pobre de vós, pensas, murchas/ Orquídeas do despudor/ Não sois Loelia tenebrosa/ Nem sois Vanda tricolor:/ Sois frágeis, desmilinguidas/ Dálias cortadas ao pé/ Corolas descoloridas/ Enclausuradas sem fé,/ Ah, jovens putas das tardes/ O que vos aconteceu/ Para assim envenenardes/ O pólen que Deus vos deu?/ No entanto crispais sorrisos/ Em vossas jaulas acesas/ Mostrando o rubro das presas/ Falando coisas do amor/ $\mathrm{E}$ às vezes cantais uivando/ Como cadelas à lua/ Que em vossa rua sem nome/ Rola perdida no céu.../ Mas que brilho mau de estrela/ Em vossos olhos lilases/ Percebo quando, falazes,/ Fazeis rapazes entrar!/ Sinto então nos vossos sexos/ Formarem-se imediatos/ Os venenos putrefatos/ Com que os envenenar/ Ó misericordiosas!/ Glabras, glúteas caftinas/ Embebidas em jasmim/ Jogando cantos felizes/ Em perspectivas sem fim/ Cantais, maternais hienas/ Canções de caftinizar/ Gordas polacas serenas/ Sempre prestes a chorar./ Como sofreis, que silêncio/ Não deve gritar em vós/ Esse imenso, atroz silêncio/ Dos santos e dos heróis!/ E o contraponto de vozes/ Com que ampliais o mistério/ Como é semelhante às luzes/ Votivas de um cemitério/ Esculpido de memórias!/ Pobres, trágicas mulheres/ Multidimensionais/ Ponto morto de choferes/ Passadiço de navais!/ Louras mulatas francesas/ Vestidas de carnaval:/ Viveis a festa das flores/ Pelo convés dessas ruas/ Ancoradas no canal?/ Para onde irão vossos cantos/ Para onde irá vossa nau?/ Por que vos deixais imóveis/ Alérgicas sensitivas/ Nos jardins desse hospital/ Etílico e heliotrópico?/ Por que não vos trucidais/ Ó inimigas? ou bem/ Não ateais fogo às vestes/ $E$ vos lançais como tochas/ Contra esses homens de nada/ Nessa terra de ninguém!" (Moraes, 1980, p. 102-104).
} 
Essa pode ser considerada a concepção dominante hoje, mas não foi sempre assim. Por um bom tempo, acreditou-se que tão melhor seria a obra de arte - e, portanto, aí está inclusa a literatura -, quão melhor ela conseguisse imitar a realidade. Não à toa, Aristóteles (1973, p. 440-471) afirma que incorre em erro o poeta que representa o impossível - erro talvez desculpável, diz, mas ainda assim um erro. Para o filósofo, a qualidade da obra literária deve ser avaliada pela sua capacidade de imitar a realidade; a obra literária é mimética. Somente com o advento do Renascimento, mais precisamente entre os séculos XVII e XVIII, tal tese começou a perder força. Na medida em que o homem passa a se assemelhar a Deus - e não apenas a estar submisso a ele -, passa, também, a poder ser um criador, agora, torna-se permitido ao artista conceber o seu próprio microcosmos (Todorov, 2012).

A partir desse momento, a obra literária deixa de ser avaliada pela sua fidelidade na representação da realidade, pela sua veracidade, e passa a ser qualitativamente examinada através da sua coerência interna, da sua verossimilhança. Ao lermos uma obra literária, não exigimos que ela necessariamente se adéque ao que entendemos como realidade. A título de exemplo, ao lermos um livro de literatura fantástica, ou uma fábula, aceitamos que "coisas estranhas" aconteçam, assim como que animais falem, embora tenhamos plena consciência de que, em nosso mundo real, isso é impossível. Exigimos, porém, que o que é dito seja adequado ao mundo descrito - e, ao mesmo tempo, criado - pela obra. Ou seja, exigimos que aquele universo literário seja internamente coerente.

Toda narrativa é composta por um conjunto de atos que se encadeiam mediante sucessão ou transformação. A sucessão diz respeito ao concatenamento meramente cronológico dos acontecimentos: determinado fato A, revelado no início do romance, está concatenado com o fato $\mathrm{B}$, revelado posteriormente, na medida em que aquele limita a criação deste último. Por exemplo, logo no início de Memórias póstumas de Brás Cubas (Assis, 2013), o narrador-protagonista nos revela que está morto, dessa maneira, a princípio, seria uma incoerência se, mais à frente, nos fosse revelado que Brás Cubas ainda vive. A transformação, por sua vez, refere-se aos atos que, ao se relacionarem, revelam alguma mudança, a qual pode ser dos mais diferentes tipos, como "negação", "transformação de modo", 
"transformação de intenção" (Todorov, 1980, p. 61-74)... A peça Otelo (Shakespeare, 1974) exemplifica bem tal tipo de concatenação, pois, motivado pelo desejo de vingança, Iago, por diversas vezes, planeja determinadas ações, que, posteriormente, concretiza - como quando planeja despertar o ciúme de Otelo através do lenço de linho que ele ofereceu a Desdémona e, pouco depois, efetivamente o faz -, o que revela uma transformação em virtude da intenção do personagem.

Enfim, não é necessário, para o presente trabalho, analisar pormenorizadamente quais os tipos de encadeamentos nas narrativas literárias. O que interessa, aqui, é perceber que os acontecimentos presentes em qualquer ficção literária estão intrinsicamente relacionados, de maneira que mais verossimilhante - e, por decorrência, melhor - será a obra que possuir menos incoerências, uma espécie de contradição inexplicável diante dos dados fornecidos pela obra literária. A necessidade de que seja inexplicável, por sua vez, decorre do fato de que a coexistência de dois acontecimentos aparentemente contraditórios não necessariamente significa incoerência, mas pode, na verdade, configurar dois atos concatenados mediante alguns dos tipos de transformação. Como explica Todorov: "a interpretação não deve demonstrar que todas as partes e níveis do texto tendem a afirmar a mesma ideia, mas que as discordâncias, as incoerências, ou seja, as contradições podem ser explicadas e justificadas" (1991, p. 166).

Entre os vários personagens de $O$ primo Basílio (Queirós, 2006), por exemplo, somos apresentados ao Conselheiro Acácio. Ao longo da obra, o Sr. Acácio, que outrora fora diretor-geral do Ministério do Reino, é retratado como um sujeito extremamente íntegro, tão zeloso pela boa moral e adequados costumes, que era até mesmo incapaz de conjugar o verbo vomitar, preferindo, com suas mãos sempre ágeis e inquietas, fazer um gesto indicativo e desculpar-se por precisar restituir. Porém, próximo ao fim do livro, é revelado que o Conselheiro Acácio escondia de todos o relacionamento que possuía com a sua criada, o que, no contexto histórico em que o livro foi escrito, seria um vexame, uma imoralidade. Embora ambos os fatos possam parecer contraditórios, tal transformação na representação da personagem explica-se e justifica-se em razão da premissa ideológica presente na obra, a qual busca criticar a burguesia de Lisboa: 
apesar de buscarem passar uma imagem de sujeitos extremamente íntegros e recheados de virtudes, os burgueses portugueses, na verdade, seriam fúteis e moralmente corrompidos. Assim, tal aparente contradição, na verdade, é uma transformação ideológica.

Além do mais, a existência de uma contradição inexplicável não necessariamente significa que o leitor não será convencido. Há, inclusive, recursos literários que permitem ao escritor disfarçar as incoerências de sua obra, com o fim de que o leitor não as perceba.

Eis um exemplo desse uso, extraído de um comentário de Bodas de Fígaro: "o movimento faz esquecer a inverossimilhança. - No final do segundo ato, o Conde tinha enviado Basílio e Furta-Sol para a cidade por dois motivos precisos: prevenir os juízes e encontrar 'o camponês do bilhete' [...]. Não é nada verossímil que o Conde, perfeitamente ciente agora da presença de Cherubino de manhã no quarto da Condessa, não peça nenhuma explicação a Basílio sobre sua mentira e não tente confrontá-lo com Fígaro, cuja atitude vem lhe parecendo cada vez mais suspeita. Sabemos, e isso será confirmado no quinto ato, que sua expectativa do encontro com Susanna não é suficiente para perturbá-lo tanto quando o que está em jogo é a Condessa. Beaumarchais estava consciente dessa inverossimilhança (anotou-a em seus manuscritos), mas ele achava, com razão, que no teatro nenhum espectador se daria conta". $\mathrm{Ou}$ ainda: "O próprio Beaumarchais confessou a seu amigo Gudin de la Brenelleire 'que havia pouca verossimilhança nos mal-entendidos das cenas noturnas'. Mas acrescentou: 'Os espectadores se prestam bem a esse tipo de ilusão quando dela nasce um imbróglio divertido" (Todorov, 2003, p. 115).

Enfim, o que se impõe entender, aqui, é que, em uma obra literária, o convencimento do leitor não resulta da verdade da obra, pela sua adequação ao mundo real, mas pela sua verossimilhança, pela sua coerência interna, pela inexistência - ou existência em menor número possível - de contradições inexplicáveis. Por isso, a preocupação de um literato não é escrever uma obra verdadeira, mas crível diante das premissas que ele próprio formula, as quais são independentes da realidade.

\section{Antonio Candido e a literatura ancorada na realidade: a independência do real nos textos "fiéis" à realidade}

Compreendida a importância da verossimilhança para a obra literária, pode-se questionar se a completa independência da realidade não existiria apenas nas obras literárias que a negam em absoluto, tal qual as fábulas. 
Uma obra realista, por exemplo, na medida em que pretende ser um espelho da realidade, não estaria, portanto, limitada pelos fatos do mundo real? O convencimento do leitor não dependeria também de quão verdadeira a obra é, e não apenas de sua verossimilhança? A resposta para a primeira pergunta é que, de certa maneira, sim; já para o segundo questionamento, é um enfático não.

De certa forma, os textos literários podem ser divididos em dois tipos: aqueles que estão ancorados na realidade, e aqueles que estão à deriva. Os textos ancorados são aqueles que se preocupam em retratar um contexto histórico e social específico ${ }^{6}$. Em os Miseráveis, por exemplo, Victor Hugo (2012) retrata a sociedade francesa do séc. XIX, mais precisamente a França que existiu entre pouco antes de 1815, ano da batalha de Waterloo, e 1832, época dos motins de junho, que buscavam derrubar o rei Luís Filipe I. Essa é uma autêntica obra literária ancorada na realidade. Já os textos à deriva seriam aqueles que não estão comprometidos com retratar contextos sociais específicos, boiando livremente (Candido, 2012, p. 9-14). Tal como em Alice no país das maravilhas (Carrol, 2009), no qual Lewis Carrol pseudônimo de Charles Lutwidge Dodgson - descreve um mundo onde coelhos se atrasam, lagartas e gatos falam e a guarda real é composta por cartas de baralho.

Um texto ancorado na realidade, então, estará, de fato, limitado pelo mundo que procura retratar. O navio só poderá navegar no raio de distância que a âncora permitir. Se a obra literária pretende retratar determinado contexto histórico e social, a princípio, os seus acontecimentos estarão restritos ao que é, ou era, possível naquela sociedade. Se o autor pretende escrever uma obra literária sobre a aristocracia brasileira do início do séc. XIX, configuraria uma incoerência que os personagens dispusessem de celulares e computadores, por exemplo, visto que, à época, tais tecnologias não estavam disponíveis. Por isso, a resposta para a primeira das perguntas feitas no início deste tópico é, “de certa forma, sim”.

6 Perceba que utilizei o verbo "retratar", e não "traduzir", pois, embora apenas algumas obras retratem contextos históricos específicos, todo texto literário revela os valores e costumes de determinado sociedade, traduzindo-a. Não à toa, Antonio Candido (2014) chega a afirmar - talvez de forma exagerada, talvez não - que as melhores traduções do Brasil têm, em sua maioria, a forma literária. 
No entanto - e daqui advém a razão do de certa forma -, isso não significa que o texto literário ancorado será mais verdadeiro do que aquele que está à deriva, ou que precise sê-lo. Como explica Candido, por vezes, as obras ancoradas na realidade podem utilizar-se de estereótipos e caricaturas que em nada correspondem à realidade, acabando por ser menos verdadeiras (Candido, 2012, p. 9-14). Em O cortiço, por exemplo, Aluízio de Azevedo (2009) reproduz diversos estereótipos de classe e raça que não são verdadeiros, que não encontram correspondência na realidade. Mas, ainda assim, tais obras convencem o leitor. Isso demonstra que, ao fim de tudo, o que importa para a qualidade da obra é a sua verossimilhança, mesmo no caso daquelas que optaram por lançar a âncora ao mar. Ainda que estejamos a ler um romance que retrata o mundo real, se as "mentiras" reveladas ao longo do texto são coerentes com o restante da obra, ou seja, se, apesar de falsas, são verossimilhantes, elas serão aceitas pelo leitor.

Isso ocorre porque os traços da realidade presentes ao longo do romance são escolhidos de acordo com os interesses da própria narrativa, que determina, assim, a maneira como tais traços do mundo real serão abordados:

\begin{abstract}
Mesmo no caso de uma orientação direta para a realidade, o campo da realidade considerado, ainda que limitado a um fato, possui um contexto e um foco dos quais recebe sua organização... A realidade efetiva é exposta em grandes linhas, o acontecimento inscreve-se exclusivamente na trama da urdidura principal $e$ apenas na medida em que seja necessário para a reprodução da situação psicológica fundamental (Skaftymov apud Todorov, 2003, p. 23, grifo nosso).
\end{abstract}

Ou seja, o mundo real adentra no romance apenas naquilo que é extremamente necessário, e, ainda assim, o faz de acordo com as premissas do microcosmo que é a obra literária. Não à toa, se for necessário, para a verossimilhança da obra, caricaturar determinados traços sociais e estereotipar determinadas classes, o autor o fará, tal qual Aluízio de Azevedo (2009) faz com as mulheres negras, animalizando-as, e com os portugueses, tornando-os vítimas dos trópicos.

E, por isso, para a segunda pergunta feita no início deste tópico, a resposta precisa ser um enfático não. As obras literárias ancoradas na realidade não precisam ser verdadeiras, precisam, apenas, ser 
verossimilhantes, assim como a literatura que optou por estar à deriva. $\mathrm{Na}$ realidade, sequer há a preocupação em ser verdadeiro. Tanto que, quando necessário à verossimilhança da obra, a realidade pode ser distorcida, caricaturizada.

\title{
O DIREITO ENQUANTO FICĈ̃O: A PREPONDERÂNCIA DO VEROSSÍMIL SOBRE O VERDADEIRO
}

\begin{abstract}
Um dia, no século V a.C., na Sicília, dois indivíduos discutem; sucede um acidente. No dia seguinte eles comparecem diante das autoridades que devem decidir qual dos dois é culpado. Mas como escolher? A altercação não ocorreu sob os olhos dos juízes, que não puderam observar e constatar a verdade; os sentidos nada podem; resta apenas um meio: escutar o relato dos queixosos. Dessa forma, a posição destes últimos se modifica: não se trata de estabelecer uma verdade (o que é impossível), mas de se aproximar dela, de dar uma impressão de verdade; e essa impressão será tanto mais forte quanto mais hábil for o relato (Todorov, 2003, p. 113).
\end{abstract}

O que se pretende demonstrar aqui não é algo original, sequer novo. Talvez entre os juristas, as semelhanças entre o direito e a literatura, no que toca à importância da verossimilhança, seja algo recente e ainda pouco debatido. Porém, já há muito que tal semelhança é notada e estudada. O trecho de Todorov acima, originalmente publicado em 1971, deixa isto bastante claro. E, se aceitarmos comparações menos específicas e pouco versadas na teoria literária, é possível encontrar escritos ainda mais antigos, como quando Platão (1993) argumenta que os juízes não podem conhecer o que de fato ocorreu, ou seja, a verdade; assim como os poetas, que não estão comprometidos com o verdadeiro.

Enfim. O objetivo do presente trabalho, e deste tópico, é demonstrar que na prática jurídica, por assim dizer, não é preciso ser verdadeiro, é preciso ser verossimilhante, tal como nas ficções literárias. E é por isso que a atividade desempenhada pelo autor de uma obra literária se assemelha bastante àquela desenvolvida pelos operadores do direito: o advogado, ao propor determinada tese jurídica no tribunal, ou o juiz, ao propor uma solução para o feito, escreve um texto ancorado na realidade; ou seja, embora esteja limitado pela realidade que retrata, a escolha dos fatos que revela, assim como o enfoque que é dado, está sujeito à verossimilhança, de tal maneira que, quando for necessário sacrificar a verdade em prol da verossimilhança, isso será não apenas feito, mas aceito. 


\section{O processo judicial enquanto parente não tão distante da narrativa literária}

O direito é composto por uma série de conteúdos prescritivos que buscam, sempre que necessário, dirimir conflitos absorvendo as inseguranças deles provenientes - o que não significa a produção de consensos. O direito destina-se à oferta de condições para a produção de decisões (Ferraz Jr., 2011). Se há dissenso entre dois homens sobre a qual dos dois deve pertencer determinado imóvel, por exemplo, o direito oferecerá uma resposta. Provavelmente, aquele que "perder" o imóvel não ficará contente; porém, a insegurança proveniente da incerteza de quem seria o legítimo proprietário e, portanto, portador dos direitos e deveres decorrentes de tal condição, restará solucionada.

No entanto, o direito nunca possui apenas uma resposta possível. De fato, por vezes, existirão respostas já sedimentadas na comunidade jurídica, o que poderá dificultar o convencimento por outras vias, mas isso não significa que elas sejam as únicas respostas possíveis. O direito não é um sistema em sentido lógico, que permite deduções resguardadas por um status de completa certeza. $\mathrm{Na}$ realidade, ele é composto por uma pluralidade de sistemas, que produzem, cada um, uma resposta, existindo, assim, diversas respostas possíveis (Viehweg, 2008).

Essas várias respostas, por sua vez, podem ser "qualitativamente" avaliadas a partir da sua adequação ao "microcosmos jurídico": a formulação de uma resposta para um problema jurídico exige a mínima concordância com os usos e sentidos dos conceitos jurídicos já estabelecidos, os quais, em tese, não podem ser alterados pelo litígio (os tais dogmas jurídicos). Percebe-se, assim, que, quando estão diante do magistrado e necessitam convencê-lo de que a tese sugerida é racional (Ferraz Jr., 2015), as partes precisam demonstrar a coerência interna da solução apresentada. Ou seja, não é preciso demonstrar o quanto a tese jurídica se adéqua à realidade, o quanto é verdadeira, mas sim o quanto é coerente com o conjunto de prescrições jurídicas ao qual as partes se submetem, o quanto é verossimilhante; como explica García Amado,

Cuando defendemos en cualquier ambito de la actividade jurídica que la interpretación correcta de la norma $x$ é esta o aquella, o que el verdadero alcance del derecho y que el texto constitucional consagra es de tal modo o tal otro, no describimos realidades preexistentes al discurso, sino que tratamos de persuadir al destinatario de nuestro 
discurso de que la realidad es así como la contamos (2003, p.369).

Imaginemos a seguinte situação, o jovem "A", de 19 anos recémfeitos, que vendera um imóvel logo após completar 18 anos, arrepende-se do contrato de compra e venda que realizou e pretende reaver o seu bem. Para tanto, argumenta que o negócio jurídico é inválido, em virtude da sua incapacidade à época, supostamente constatável pela sua imaturidade e completo desconhecimento do mercado de imóveis. Por mais que tal tese jurídica possa ser verdadeira e adequada à realidade, ela não é coerente com o conjunto de prescrições jurídicas. Isso porque, devido ao que prescreve o art. $5^{\mathrm{o}}$ do Código Civil Brasileiro7, independente da experiência que possua, o jovem "A" era, no tempo da venda, plenamente capaz, visto que já era maior de 18 anos. No entanto, se a argumentação fosse em defesa da anulabilidade do negócio por o garoto, devido à sua inexperiência, ter se obrigado a prestação manifestamente desproporcional, a tese jurídica se tornaria coerente, por estar de acordo com o que determinam os arts. $157 \mathrm{e}$ 171, II, do Código Civil Pátrio ${ }^{8}$. Embora ambas as argumentações se baseiem nos mesmos fatos da realidade e, portanto, sejam verdadeiras, apenas uma seria admissível, pois apenas uma das soluções apresentadas seria coerente com o conjunto de prescrições jurídicas - ou seja, seria verossimilhante.

Isso ocorre porque todo processo judicial constitui uma narrativa composta pelo conjunto de todas as prescrições jurídicas válidas e vigentes, as quais, por sua vez, não precisam, necessariamente, adequar-se à realidade. Quem define o conteúdo dos conceitos jurídicos que serão usados na produção das decisões é o próprio direito, visto que tais conceitos, em si, não possuem sentido algum, só conseguindo ser compreendidos na medida em que são postos diante das prescrições jurídicas que relacionam (Ross, 2004). Como explica Ferraz Jr.:

7 "Art. 5o A menoridade cessa aos dezoito anos completos, quando a pessoa fica habilitada à prática de todos os atos da vida civil”.

8 "Art. 157. Ocorre a lesão quando uma pessoa, sob premente necessidade, ou por inexperiência, se obriga a prestação manifestamente desproporcional ao valor da prestação oposta”; “Art. 171. Além dos casos expressamente declarados na lei, é anulável o negócio jurídico: [...] II - por vício resultante de erro, dolo, coação, estado de perigo, lesão ou fraude contra credores". 
Uma norma penal, ao configurar uma hipótese de conduta - "abandonar pessoa que está sob seu cuidado, guarda, vigilância ou autoridade e, por qualquer motivo, incapaz de defender-se dos riscos resultantes do abandono; pena [...]" (Cód. Penal, art. 133) - não está apenas descrevendo-a, mas tipificando-a. Ou seja, no exemplo, não se trata de mostrar o que se designa por abandono, mas prescrever o que deva ser entendido por abandono (2014, p. 118).

Dessa maneira, ao precisarem ser coerentes com o direito, as teses jurídicas reveladas ao longo de um processo judicial precisam, apenas, ser coerentes com o próprio universo a que pertencem; tal qual os acontecimentos revelados ao longo de qualquer narrativa literária, que precisam ser coerentes apenas com o próprio universo ficcional que compõem.

Assim, a realidade importa para a narrativa jurídica tanto quanto importa para as narrativas literárias ancoradas na realidade: não existe exigência de verdade; dentro do raio de navegação permitido pela âncora, o enfoque dado à abordagem dos fatos estará sujeito exclusivamente às necessidades da narrativa processual que se pretende construir (vide Aluízio de Azevedo); existe apenas a exigência de verossimilhança, de maneira que, (a) ao revelar os fatos, a parte não poderá contradizer o estilo adotado pela própria narrativa processual (retratar um contexto histórico e social específico), (b) assim como a sequência de acontecimentos, não poderá revelar incoerências inexplicáveis. Ou seja, para além de constituir uma espécie de gênero literário, de tal maneira que o advogado se vale de tantos artifícios retóricos quanto um escritor (Cardozo, 1932), ou um conjunto de narrativas que, ao serem construídas, constituem a própria realidade, revelando os diversos valores que permeiam a sociedade, (Binder, Weisberg, 2000), os próprios processos judiciais, apesar de arrolarem a si a busca pela verdade, são relatos ficcionais, não possuindo a necessidade de serem verdadeiros, precisando, apenas, ser verossimilhantes, tais quais os romances.

(a) Por retratar um contexto histórico e social específico, a liberdade da narrativa processual acaba tolhida, tal como ocorre com as narrativas literárias ancoradas na realidade. Dessa maneira, não poderá um litigante argumentar que fora coagido por um gnomo para a prática de determinado negócio jurídico, o que provocaria a sua nulidade, nos termos do art. 151 do 
Código Civil Brasileiro9. Mas isso não significa que haja aí uma exigência de verdade. Há, apenas, uma exigência de que os acontecimentos revelados sejam coerentes com a premissa que a própria narrativa processual adotou (retratar um contexto histórico e social específico). Na medida em que a narrativa literária se enquadra em determinado estilo, ela precisa obedecer às regras desse estilo, sob o risco de provocar inverossimilhanças (Todorov, 2003, p. 118-123). Inverossimilhança e não inverdade porque, como dito, os acontecimentos não precisam ser coerentes com a realidade (sob o risco de tornar-me chato, reitero o exemplo de Aluízio de Azevedo), mas com o próprio universo criado pela narrativa literária, do qual tal "lei do gênero" também faz parte. Inclusive, até mesmo as narrativas à deriva precisam obedecer à suposta "lei do gênero": uma fábula em que os animais não falem, por exemplo, será inverossimilhante.

(b) Além do mais, os fatos jamais serão questionados ao longo de uma narrativa processual por não serem verdadeiros. O seu questionamento só ocorre quando eles são inverossimilhantes, ou seja, quando são incoerentes do ponto de vista interno, assim como ocorre com a ficção literária. Como determina o art. 341, do Código de Processo Civil Brasileiro ${ }^{10}$, a princípio ${ }^{11}$, serão aceitos os fatos revelados pelo autor que não forem contestados pelo réu. Assim, se o autor diz "A" e não existe contra-argumentação do réu, "A" será presumido verdadeiro; porém, se o autor diz "A" e o réu diz "não A", instaura-se, no seio da narrativa jurídica, uma incoerência que precisa ser solucionada. Ou seja, a preocupação com os acontecimentos revelados só surge na medida em que importa inverossimilhança. Quando não há incoerência interna, os fatos serão presumidos verdadeiros, mesmo que não

9 “Art. 151. A coação, para viciar a declaração da vontade, há de ser tal que incuta ao paciente fundado temor de dano iminente e considerável à sua pessoa, à sua família, ou aos seus bens".

10 "Art. 341. Incumbe também ao réu manifestar-se precisamente sobre as alegações de fato constantes da petição inicial, presumindo-se verdadeiras as não impugnadas, salvo se: I não for admissível, a seu respeito, a confissão; II - a petição inicial não estiver acompanhada de instrumento que a lei considerar da substância do ato; III - estiverem em contradição com a defesa, considerada em seu conjunto".

11 Embora existam exceções a essa regra geral (incisos I, II e III do próprio art. 341), elas referem-se a situações em que também há incoerência interna e, portanto, inverossimilhança, seja em relação aos conjuntos de prescrições jurídicas que compõem a narrativa processual (incisos I e II), seja em relação à própria sequência de acontecimentos da narrativa processual. 
o sejam. Nesse sentido, é pertinente o ensinamento de Arenhart e Marinoni:

não é objetivo do juiz encontrar a verdade (absoluta) no processo. Conquanto possa essa meta continuar como elemento mítico - e objetivo utópico - da atividade jurisdicional (mesmo para que se possa assegurar a qualidade da pesquisa efetivada pelo magistrado e, consequentemente, do resultado obtido), não se pode acreditar que, concretamente, esse ideal seja realizado no processo, ou mesmo que ele a isto se destina. Todavia, se isso é correto, qual seria então a função da prova no processo? Constitui-se, ao que parece, em meio retórico, indispensável ao debate judiciário. $\mathrm{O}$ processo deve ser visto como palco de discussões; a tópica é o método da atuação jurisdicional e o objetivo não é a reconstrução do fato, mas o convencimento dos demais sujeitos processuais (2008, p. 257-258).

Assim, na medida em que o processo judicial preocupa-se não em corresponder à realidade, mas em convencer as partes, tal qual as narrativas literárias, ele precisa ser verossimilhante, portanto, livre de incoerências inexplicáveis. É nesse sentido que o direito processual civil adota o princípio da verdade formal: o verdadeiro é aquilo que assim for estabelecido em meio ao processo, mesmo que não corresponda ao que efetivamente ocorreu na realidade (Alvim, 2012, p. 230).

Porém, tal preocupação com o verossimilhante em detrimento do verdadeiro não é algo exclusivo do direito processual civil, mas é característica de qualquer direito processual, inclusive aqueles preocupados com a verdade material. Nos processos administrativo e penal, a ideia de verdade material funciona muito mais como uma facilitadora da produção de incoerências, do que como uma garantia de que a narrativa processual corresponderá à realidade. O que ocorre nesses direitos processuais é que, ao invés de apenas as partes poderem relatar fatos, a legislação permite que os julgadores também possam incorporar acontecimentos à narrativa processual, o que aumenta, assim, a chance de serem produzidas incoerências internas. É nesse sentido que o art. 156 do Código de Processo Penal $^{12}$ permite ao juiz ordenar de ofício a produção antecipada de provas,

\footnotetext{
12 “Art. 156. A prova da alegação incumbirá a quem a fizer, sendo, porém, facultado ao juiz de ofício: I - ordenar, mesmo antes de iniciada a ação penal, a produção antecipada de provas consideradas urgentes e relevantes, observando a necessidade, adequação e proporcionalidade da medida; II - determinar, no curso da instrução, ou antes de proferir sentença, a realização de diligências para dirimir dúvida sobre ponto relevante”.
} 
assim como a realização de diligências para solucionar eventuais dúvidas; e, no que diz respeito ao processo administrativo:

O princípio da verdade material, também denominado de liberdade na prova, autoriza a Administração a valer-se de qualquer prova que a autoridade processante ou julgadora tenha conhecimento, desde que a faça trasladar para o processo. É a busca da verdade material em contraste com a verdade formal. Enquanto nos processos judiciais o Juiz deve-se cingir às provas indicadas no devido tempo pelas partes, no processo administrativo a autoridade processante ou julgadora pode, até o final do julgamento, conhecer de novas provas, ainda que produzidas em outro processo ou decorrentes de fatos supervenientes que comprovem as alegações em tela (Meirelles, 1991, p. 581).

Ou seja, não é que as narrativas processuais penais e administrativas sejam verdadeiras, sendo fundamental que os acontecimentos revelados correspondam à realidade. Também nesses direitos processuais o que importa é a mera verossimilhança. Porém, há uma margem maior para a produção de incoerências internas no que diz respeito à sequência dos acontecimentos revelados, visto que as partes não são as únicas que podem incluir acontecimentos nas narrativas processuais. Mas, assim como no processo civil, um acontecimento não precisará ser verdadeiro, mas apenas verossimilhante, para ser presumido como verdade.

\section{ANÁLISE DE CASO \\ (Agravo de Instrumento $\mathrm{n}^{\circ}$ o0125140-23.2005.8.17/PE)}

A decisão proferida em meio ao Agravo de Instrumento $n^{0}$ o012514023.2005.8.17.0001, julgado pelo Tribunal de Justiça do Estado de Pernambuco (TJPE), é bastante exemplificativa do que se está a expor aqui. Diz a ementa do Acórdão:

AGRAVO DE INSTRUMENTO. UNIÃO. PARTICIPAÇÃO NO FEITO. IMPOSSIBILIDADE. NÃO DEMONSTRADO INTERESSE JURÍDICO. INCOMPETÊNCIA DA JUSTIÇA FEDERAL. RECURSO NÃO PROVIDO.

1. A jurisprudência do STJ consigna que o mero interesse econômico da União - fundado no art. $5^{\circ}$, parágrafo único, da Lei n. 9.469/97 - não é suficiente para atrair a incidência do art. 109, I, da Constituição Federal. Há que ser demonstrado o evidente interesse jurídico.

2. As sociedades de economia mista só têm foro na Justiça Federal, quando a União intervém como assistente ou opoente.

3. Agravo não provido (Brasil, 2012). 
Conforme é possível concluir através da leitura do Acórdão referido e da decisão recorrida, o processo originário é uma ação de cobrança ajuizada pelas Construtoras Norberto Odebrecht S.A. e Queiroz Galvão S/A em face da Companhia Brasileira de Trens Urbanos (CBTU). Em meio ao trâmite da ação, por sua vez, a União requereu seu ingresso no feito na qualidade de assistente simples, com fundamento no art. $5^{\circ}$, parágrafo único, da Lei $\mathrm{n}^{\mathrm{o}}$ 9.469/1997 c/c art. 50 do Código de Processo Civil (CPC) então vigente, atual art. 119 do $\mathrm{CPC} / 15$.

A União argumentara que, embora a CBTU seja uma sociedade de economia mista, a federação possui $99,9 \%$ das suas ações. Dessa maneira, os prejuízos decorrentes de uma eventual condenação recairiam, quase que em sua totalidade, sobre a União, o que demonstraria de maneira suficiente o seu interesse no processamento do feito.

Como se percebe, as alegações da União possuem absoluta correspondência com a realidade. É evidente o interesse da União, visto que, embora a CBTU possua autonomia financeira em virtude de ser uma sociedade de economia mista, indiretamente, os custos de uma condenação recairiam quase que apenas sobre a União. Ou seja, as alegações da União parecem verdadeiras.

Porém, como decidiu o julgado, elas não são verossimilhantes. Isso porque, de acordo com o que prescrevem os diplomas normativos que compõem a narrativa processual, mais precisamente a jurisprudência do STJ, o interesse econômico não é suficiente para configurar interesse jurídico, o qual se caracteriza por alguma das seguintes circunstâncias:

a) a de ser titular de uma relação jurídica sujeita a sofrer efeitos reflexos da sentença, caso em que pode intervir como assistente simples (CPC, art. 50); ou b) a de ser cotitular da própria relação jurídica que constitui o objeto litigioso, caso em que poderá intervir como assistente litisconsorcial (CPC, art. 54) (Brasil, 2007).

Dessa feita, embora a tese defendida pela União possa ser adequada à realidade, não é verossimilhante, visto que é incoerente com o conceito de interesse formulado pelo próprio direito, razão pela qual o Agravo de Instrumento interposto pela União acabou por ser improvido pelo TJPE. Como se percebe, nas narrativas processuais, o dever de verossimilhança prepondera sobre uma eventual necessidade de que a narrativa seja verdadeira, assim como nas ficções literárias. 


\section{CONCLUSÃO}

Buscar que a narrativa processual corresponda à realidade, desejar que o processo seja verdadeiro, é algo plenamente possível e, inclusive, benéfico. Tal desejo promoveu mudanças (Foucault, 2003) que, a meu ver, irrefutavelmente, colaboraram para uma prestação jurisdicional mais efetiva e justa. O presente trabalho, assim, não é uma afirmação de que os processos judiciais não devam procurar conhecer o que efetivamente ocorreu, por isso ser supostamente impossível. Tampouco é uma tentativa de argumentar que na narrativa processual tudo é permitido, de maneira tal que a realidade não possuiria importância alguma. Até mesmo porque, como explicado anteriormente, nas narrativas ancoradas, o raio de navegação é diminuto, quando comparado ao das narrativas à deriva; o que, por sua vez, já revela certa importância do que se compreende como mundo real na construção do processo.

O objetivo do presente trabalho é, apenas, constatar semelhanças entre as formas como, hoje, as narrativas processuais e literárias são escritas, com o fim de tornar possível o estudo do direito a partir de lentes tipicamente literárias.

Ao defender uma "epistemologia dos desejos", Warat (2000) explica que o primeiro passo para a quebra das correntes que limitam os nossos anseios é atentar para as próprias correntes, que, hoje, passam despercebidas. Embora as possibilidades jurídicas do ordenamento estejam limitadas por aspectos ideológicos e históricos, não há qualquer discussão em torno de tais valores e concepções, simplesmente porque não os notamos.

E, em meio a tal problema, acredito que a literatura pode oferecer um bom auxílio. As narrativas literárias estão sempre permeadas por uma série de valores, afinal de contas "a literatura é essencialmente uma reorganização do mundo em termos de arte" (Candido, 2014, p. 187), e, se a realidade está repleta de aspectos ideológicos, é natural que isto transpareça em seu espelho. Por sua vez, a teoria literária parece ter desenvolvido conceitos que permitem tornar mais claros os valores contidos nas narrativas analisadas. Então, se a ficção literária e a narrativa processual são assemelhadas - e é preciso saber se de fato o são e, se sim, em que medida - porque não se utilizar de tais conceitos típicos dos 
literatos para estudar as narrativas processuais, com o fim de tornar mais evidentes tais valores que nos acorrentam?

Embora a filosofia e a teoria geral do direito tenham conseguido, com certo sucesso, estudar os valores que compõem os ordenamentos jurídicos contemporâneos enquanto um conjunto de prescrições, o que me parece é que pouco se progrediu no estudo dos valores contidos no uso específico de conceitos jurídicos. E é primordialmente a estes valores, e não àqueles, que me refiro.

Conhecer tais valores é essencial para o exercício de um direito democrático. Ao impor padrões de normalidade à sociedade, o direito exclui costumes e violenta pessoas (Foucault, 2010). Portanto, é necessário que, ao impor tais padrões, os discutamos politicamente com o fim de reduzir os danos provocados aos grupos sociais eventualmente envolvidos; mas, para isso, é preciso que, antes, percebamos os valores políticos presentes nos conceitos jurídicos. Apenas após perceber tais valores e delimitá-los, será possível discutir a sua permanência ou substituição - somente após identificar a corrente, é possível destruí-la.

Enfim. Como disse, o objetivo do presente trabalho é constatar eventuais semelhanças entre a narrativa processual e a narrativa literária, percebendo os processos judiciais como ficções ancoradas na realidade. E acredito que isso ele já fez de maneira suficiente.

\section{REFERÊNCIAS}

ALVIM, José Eduardo Carreira. Teoria geral do processo. Rio de Janeiro: Forense, 2012. 294p.

AMADO, Juan Antonio García. Ensayos de filosofia jurídica. Bogotá: Temis, 2003.

ARISTÓTELES. Os pensadores; Tópicos, Dos argumentos sofísticos, Metafísica (Livros I e II), Ética a Nicômaco e Poética. São Paulo: Abril, 1973. 481p.

ASSIS, Machado de. Memórias póstumas de Brás Cubas. São Paulo: Saraiva, 2013. 231p.

AZEVEDO, Aluísio. O cortiço. São Paulo: Ática, 2009. 100p.

BRASIL. Superior Tribunal de Justiça. Recurso Especial no 877172 - PA, Relator: Min. Teori Albino Zavascki, Primeira Turma, julgado em: o8 out. 2007. 
BRASIL. Tribunal de Justiça do Estado de Pernambuco. Agravo de Instrumento $\mathrm{n}^{0}$ 00125140-23.2005.8.17, Relator: Des. Stênio Neiva Coelho, Primeira Câmara Cível, julgado em: 22 dez. 2015.

BINDER, Guyora; WEISBERG, Robert. Literary Criticism of Law. Princeton: Princeton University Press, 2000.

CANDIDO, Antonio et al. A personagem de ficção. São Paulo: Perspectiva, 2009. 119p.

CANDIDO, Antonio. $O$ discurso e a cidade. Rio de Janeiro: Ouro sobre Azul, 2010. 288p.

CANDIDO, Antonio. Literatura e sociedade. Rio de Janeiro: Ouro sobre Azul, 2014. 204p.

CARDOZO, Benjamin N. Law and Literature. Yale Law Journal, New Haven, n. 48, p. 489-507, 1932.

CARROL, Lewis Carroll. Alice no país das maravilhas. São Paulo: Cosac Naify, 2009. 168p.

CASTRO JR., Torquato da Silva. Metáforas de letras em culturas jurídicas da escrita: como se é fiel à vontade da lei? In: BRANDÃO, Claúdio; CAVALCANTI, Francisco; ADEODATO, João Maurício (Org.). Princípio da legalidade; da dogmática jurídica à teoria do direito. Rio de Janeiro: Forense, 2009.

FERRAZ JÚNIOR, Tércio Sampaio. Introdução ao estudo do direito: técnica, decisão e dominação. São Paulo: Atlas, 2011. 36op.

FERRAZ JÚNIOR, Tércio Sampaio. A ciência do direito. São Paulo: Atlas, 2014. 152p.

FERRAZ JÚNIOR, Tércio Sampaio. Direito, retórica e comunicação: subsídios para uma pragmática do discurso jurídico. São Paulo: Atlas, 2015. 264p.

FOUCAULT, Michel. A verdade e as formas jurídicas. Rio de Janeiro: NAU, 2003. 158p.

FOUCAULT, Michel. Os anormais; Curso no Còllege de France (19741975). São Paulo: WMF Martins Fontes, 2010. 344p.

GHIRARDI, José Garcez. O teatro, a consciência do rei: o papel da literatura na formação democrática do jurista. Anamorphosis - Revista Internacional de Direito e Literatura, v. 2, n. 1, p. 53-67, 2016.

HUGO, Victor. Os miseráveis. São Paulo: Cosac Naify, 2012. 1974p.

KAFKA, Franz. O processo. São Paulo: Companhia das letras, 2013. 332p.

MEIRELLES, Helly Lopes. Direito administrativo brasileiro. São Paulo: Revista dos Tribunais, 1991. 798p.

MITTICA, M. Paola. O que acontece além do oceano? Direito e Literatura na Europa. Anamorphosis - Revista Internacional de Direito e Literatura, v. 1, n. 1, p. 3-36, 2015.

MORAES, Vinicius de. Antologia poética. Rio de Janeiro: José Olympio, 1980. 224p. 
PLATÃO. A república. Porto: Fundação Calouste Gulbenkian, 1993. 512p.

QUEIRÓS, Eça de. O primo Basílio. São Paulo: Ática, 2006. 352p.

ROSS, Alf. Tû-Tû. São Paulo: Quartier Latin do Brasil, 2004. 54p.

SHAKESPEARE, Willian. Otelo. Porto: Lello \& Irmão, 1974. 278p.

SÓFOCLES. Édipo-rei, Antígona. São Paulo: Martin Claret, 2016. 254p.

TODOROV, Tzvetan. Os gêneros do discurso. São Paulo: Martins Fontes, 1980. 305p.

TODOROV, Tzvetan. As morais da história. Lisboa: Europa-América, 1991. 292p.

TODOROV, Tzvetan. Poética da prosa. São Paulo: Martins Fontes, 2003. 332p.

TODOROV, Tzvetan. A literatura em perigo. Rio de Janeiro: Difel, 2012. 96p.

VIEHWEG, Theodor. Tópica e jurisprudência: uma contribuição à investigação dos fundamentos jurídico-científicos. Porto Alegre: Safe, 2008. $126 \mathrm{p}$.

WARAT, Luis Alberto. A ciência jurídica e seus dois maridos. Santa Cruz do Sul: EDUNISC, 2000. 199p.

WOOD, James. Como funciona a ficção. São Paulo: Cosac Naify, 2012. 224p.

Idioma original: Português

Recebido: 22/10/16

Aceito: 12/12/16 